\title{
Lundu canção e choro: implicações com a sociedade goiana que cultivou saraus e serestas
}

\author{
Magda de Miranda Clímaco (Universidade Federal de Goiás, Goiânia, Goiás, Brasil) \\ magluiz@hotmail.com \\ Ludmylla Cristina Guilardi (Universidade Federal de Goiás, Goiânia, Goiás, Brasil) \\ ludmyla_guilardi@hotmail.com
}

\begin{abstract}
Resumo: Objetivou-se investigar as implicações socioculturais que estiveram relacionadas com a prática ou com a ausência dos gêneros musicais lundu canção e choro no cenário musical de Vila Boa (atual Cidade de Goiás), que, no final do século XIX e início do século XX, cultivou saraus e serestas. A trajetória metodológica que levou à historiografia goiana e a algumas peculiaridades dos gêneros e da sociedade em questão permitiu constatar que foram muito pouco praticados por uma elite goiana que não via com bons olhos as atividades musicais ligadas mais diretamente à cultura dos escravos e a certa modalidade de boemia.
\end{abstract}

Palavras-chave: Lundu canção; Choro; Sociedade Goiana; Saraus e Serestas; Interações.

Lundu song and Choro: implications with the Goiana society that cultivated saraus and serenades

Abstract: The objective was to investigate the socio-cultural implications that were related to the practice or the absence of the musical genres lundu song and choro in the musical scene of Vila Boa (present-day city of Goiás), which, at the end of the 19th century and beginning of the 20th century, cultivated saraus and serenades. The methodological trajectory that led to the historiography of Goiás and to some peculiarities of the genres and society in question allowed verify that they were very little practiced by a Goiana elite that did not see with good eyes the musical activities linked more directly to the culture of the slaves and to certain modality of bohemia.

Keywords: Lundu song; Choro; Goiana society; Saraus and Serenades; Interactions.

\section{Introdução}

Este trabalho teve como ponto de partida os resultados de uma pesquisa anterior, Saraus e Serestas em Goiás: processos identitários e interações com a modinha (GUILARDI; CLÍMACO, 2016), que propiciou constatar, no final do século XIX e início do século XX, grande investimento da capital de Goiás (Vila Boa - depois Cidade de Goiás) ${ }^{1}$ no gênero musical modinha e em transcrições de árias de ópera para voz e piano. Do mesmo modo possibilitou descobrir algumas peculiaridades desta sociedade, cuja elite se empenhava em cultivar hábitos e práticas relativos a uma "sociedade moderna”, investindo muito na cultura, sobretudo na música e na literatura, o que favoreceu uma circunstância em que a mulher teve um papel importante na produção de saraus lítero-musicais, em que os gêneros mencionados foram muito cultivados.

O desenrolar e os resultados dessa primeira pesquisa, no entanto, trouxeram inquietações quanto à inexistência de uma menção a dois outros gêneros musicais na historiografia musical local: o lundu canção e o choro. Estes dois gêneros interagiram com a trajetória da modinha na cidade do Rio de Janeiro no recorte de tempo aqui privilegiado, um período que se caracterizou por uma grande efervescência e desenvolvimento da música popular urbana na então capital do país (TINHORÃO, 1998; 2013). Essa constatação, junto ao fato de que o Rio de Janeiro era muito procurado pelos filhos da elite goiana com a finalidade de terminar os seus estudos, de onde traziam para Goiás as novidades e novos hábitos e práticas (RODRIGUES, 1982, p. 111), aumentou mais a curiosidade em saber sobre a prática do lundu canção e do choro em Vila Boa/Cidade Goiás. Foi proposto, então, investigar se esses gêneros também interagiram com a sociedade goiana da época, ou, mesmo, verificar 
se esta interação não aconteceu devido às características desta sociedade que, porventura, possa ter renegado as suas peculiaridades estilísticas e procedência cultural.

O lundu-canção, que teve uma trajetória sempre relacionada ao desenvolvimento da modinha, desde sua apresentação na corte portuguesa pelo brasileiro Domingos Caldas Barbosa no final do século XVIII, até o seu desenvolvimento no cenário musical brasileiro no século XIX, é considerado hoje, por autores como Tinhorão (2013, p. 57-68), um dos primeiros gêneros da música popular brasileira. Comentando a relação intrincada que este gênero sempre teve com a modinha no transcorrer do século XIX no cenário brasileiro, (demonstrada também na abordagem das manifestações musicais de Caldas Barbosa no final do século XVIII no cenário português), Sandroni (2001, p. 41), citando autores como Mário de Andrade, Mozart Araújo e Bruno Kiefer, observou:

o lundú e a modinha têm estado indissoluvelmente associados na historiografia da música brasileira. [...] Esse tratamento conjunto que os gêneros receberam por parte dos estudiosos reflete o que Araújo chama de "conexões históricas". Andrade escreve em seu clássico estudo sobre a primeira: "o fato é que modinha e lundum andaram muitíssimo baralhados". E Kiefer: "No século passado não era rara a confusão entre modinha e lundú". Para discutir o lundú será, pois necessário abordar também a modinha.

Estes dois gêneros estiveram até certo ponto estilísticamente relacionados e foram cultivados paralelamente, portanto, tanto na corte portuguesa quanto na sociedade carioca. No Rio de Janeiro, no entanto, no transcorrer do século XIX, a modinha foi estabelecendo um diálogo cada vez mais intenso com as árias de ópera e com a valsa. Isto caracterizou frases mais melodiosas, e, algumas vezes, no compasso ternário, ao invés da contrametricidade acentuada e do uso do compasso binário que lhe foi peculiar desde o surgimento, embora tenha preservado o teor mais sentimental de suas letras (KIEFER, 1977, p. 21; TINHORÃO, 1998, p. 120). Estilisticamente foi se modificando, ganhando peculiaridades que favoreceram a sua entrada nos salas de concerto, ao contrário do lundu canção, que passou a fazer parte, sobretudo, dos Teatros de Revistas e dos picadeiros de circo, caracterizando-se cada vez mais pela contrametricidade e pelos textos picantes, humorísticos ou de crítica social (SANDRONI, 2001, p. 53). Tendo em vista o objeto de estudo deste trabalho, interessante lembrar que diferente do que aconteceu no cenário goiano, a historiografia brasileira continuou relatando a presença dos dois gêneros na capital do país da época - a cidade do Rio de Janeiro -, cujas trajetórias diferentes continuaram sendo desenvolvidas paralelamente.

O choro, por sua vez, consiste em uma música instrumental cuja formação tradicional remete a violões, cavaquinho, flauta ou bandolim, no que se aproxima da instrumentação das serestas goianas. Trata-se de um gênero que evidencia também a contrametricidade rítmica básica brasileira, uma linha melódica fluídica e o cultivo de um estilo improvisatório que se assemelha a uma variação melódica. Além de dar nome às festas que integrava nos seus primórdios, se constituiu no cerne das rodas de choro, caracterizadas pela execução de muita música numa ambiência de afeto e descontração, regada a comida e bebida. $\mathrm{O}$ relato do antigo chorão carioca Alexandre Pinto (1936, p. 10), testemunha da fase inicial do choro, confirma essa observação:

Assim agora as pessôas daquelles tempos no Rio de Janeiro recordam-se e sente n’alma a vibração das musicas daquella época: os chorões do luar, os bailes das casas de famílias, aquellas festas simples onde imperavam a sinceridade, a alegria expontanea, a hospitalidade, a comunhão de idéas e a uniformidade de vida!

A ausência do lundu canção na historiografia goiana, notada já no começo da pri- 
meira pesquisa, se tornou intrigante, assim como se tornou intrigante o choro também não ter interagido de alguma forma com a sociedade goiana que promovia saraus em suas casas e serestas ao luar. Trouxe, inclusive, questionamentos sobre o viés metodológico e ideológico que estaria por trás da historiografia abordada. Diante deste contexto, foram formuladas algumas questões: Se o lundu-canção e o choro foram praticados em Vila Boa (depois Cidade de Goiás), onde, como e por quem foram praticados? Estavam relacionados de forma mais direta a que dimensão cultural dessa sociedade? Que implicações tinham com uma trama sociocultural goiana mais ampla? Por que não constam na historiografia musical local? Tentando responder estas questões, o trabalho teve como objetivo investigar se o lundu canção e o choro foram praticados em Vila Boa/Cidade de Goiás no final do século XIX e início do século XX, buscando as implicações socioculturais que estiveram relacionadas com a sua prática ou ausência neste cenário musical que cultivou saraus e serestas. Partiu-se do pressuposto que esses gêneros foram praticados em outros eventos e manifestações musicais goianos, respondendo a anseios e investimentos de outras dimensões culturais dessa sociedade, ou mesmo de momentos mais reservados de elementos que também frequentavam os saraus e serestas. Efetivaram outros processos identitários, portanto.

Assim, ao se propor esta investigação, resolveu-se ter em vista a abordagem da música, das práticas musicais e dos autores da historiografia mencionada, na sua capacidade de significar em relação à sociedade, de evidenciar representações sociais. As representações, que têm como suporte o simbólico, segundo Chartier (2002, p. 23), se objetivam através de "constructos simbólicos", ou seja, das formulações/esquemas intelectuais, práticas e obras de um grupo social, revelando um modo particular de valoração, classificação, categorização, uma modalidade de conhecimento partilhado. Isso, numa circunstância forjadora de processos identitários, conforme também descrita por Hall (2014, p. 112), e sem negar a interferência da inevitabilidade dos encontros culturais.

Neste trabalho, portanto, no momento em que foram investigadas as relações entre obras, práticas e contexto, as representações foram consideradas um instrumento de análise tanto da música quanto das práticas e dos relatos historiográficos analisados, numa circunstância que direcionou também para Ferrara (1984, p. 356-357). Levando em conta a abordagem deste autor, que percebeu a intersubjetividade entre os mundos do compositor, do intérprete e do analista, a análise se deu em três níveis: análises sintática (análise da organização sonora e das práticas em si), ontológica (análise de elementos do contexto sociocultural implicado com as obras e práticas musicais abordadas) e semântica (identificação de significantes - representações - através da análise das obras e práticas na sua relação com os significados percebidos no estudo do contexto analisado). A análise dimensional-temática das representações sugerida por Serge Moscovici, em interação com os três níveis de análise de Ferrara, também se consistiu em suporte para esta abordagem. Utilizando o representacional como um instrumento de análise, prevendo também o suporte que o simbólico lhe dá, Moscovici (1978, p. 71) propôs três possibilidades de enfoque do objeto de estudo: o campo de representação, no qual se destacam as figuras, imagens e os conceitos; a atitude, julgamento de valor ou posição (positiva, negativa, ou neutra) do sujeito sobre o objeto da representação; e a informação, ou organização do conhecimento que um grupo social tem do objeto. Ao se objetivarem através de processos ligados ao simbólico, portanto, as representações podem evidenciar conceitos e conteúdos relacionados "às afirmações dos sujeitos sobre o objeto da representação, o que aponta as possibilidades colocadas pela análise dimensional-temática, para a percepção do conteúdo e do sentido” (MOSCOVICI, ANO apud CLÍMACO, 2008, p. 36).

Deste modo, nesta abordagem das relações do lundu canção e do choro com a so- 
ciedade goiana, o campo do representacional considerado são as obras e práticas musicais enfocadas, assim como outras fontes bibliográficas, arquivísticas e iconográficas capazes de revelar categorizações, classificações e valorações dos sujeitos pesquisados. As análises sintática, semântica e ontológica, sugeridas por Ferrara, possibilitaram a análise estrutural dos objetos de estudo e a contextualização dos cenários sociohistórico e culturais com os quais estes objetos interagiram, propiciando chegar a sentidos e significados com eles implicados, e, consequentemente, possibilitaram também chegar à atitude e à informação, conforme descritas por Moscovici. O artigo foi estruturado com esta introdução, seguida de três itens e das considerações finais. O primeiro item - A sociedade goiana e as interações culturais -consiste na abordagem de alguns elementos instituidores do cenário goiano; o segundo O lundu, o lundu canção e o choro - traz um esboço estilístico dos gêneros em questão; e o terceiro - O lundu e o choro em Goiás - aborda a historiografia e um histórico destes gêneros em Goiás, já levando também a algumas respostas às questões colocadas.

\section{A sociedade goiana e as interações culturais}

Vila Boa surgiu na época do ciclo do ouro no Brasil, da interação de pessoas de várias regiões do país que vinham atrás desse metal, principalmente paulistas e portugueses que conviviam de perto com o povo autóctone da região: os indígenas (RODRIGUES, 1982, p. 17). Segundo Souza (2001, p. 19), com a exploração do ouro houve a vinda de muitos negros para Goiás, "eles eram feitos escravos ou já chegavam nessa condição, quando eram importados de alguma capitania do Brasil para o trabalho das minas". Foram trazidos da Bahia, de Minas Gerais, de São Paulo, de Mato Grosso e do Sul, representando diversas etnias, e o trabalho inicialmente era ligado à mineração. $\mathrm{O}$ autor (SOUZA, 2001, p. 26) afirma que através de pesquisas e discussões a respeito, chegou-se a um consenso de que a predominância era de bantos, que tinham "como grupo de linhagem os angolas, congos e moçambicanos". Lembra que "os negros do Congo trouxeram a exuberância e o tom alegre de suas danças [...], enquanto os angolas eram 'humildes', alegres e muito inteligentes". Observa ainda que "os moçambiques eram de cor retinta e as mulheres gostavam de música, balangandãs e eram sempre preferidas nas casas de família”.

Por outro lado, como todas as pequenas vilas que surgiam nesse contexto, Vila Boa interagiu com as ordens religiosas de origem europeia, com os rituais de suas igrejas. Contexto, rituais e instituições religiosas que se mesclavam com o contexto profano, ocasionando as chamadas "festas coloniais", que eram alimentadas pela intensa circulação de pessoas, e, no que interessa mais de perto a esse trabalho, pelo cultivo da música, pela circulação de partituras e atividades musicais diversas (MENDONÇA, 1981). Os africanos, por sua vez, por possuir uma religião divergente da que era imposta a eles (Católica Apostólica Romana), constantemente eram proibidos de realizar os seus rituais, tinham as suas manifestações culturais limitadas. No entanto, mesmo quando faziam um festejo católico, misturavam elementos de sua cultura. "O batuque, a dança, o ritmo frenético, a festa, as ornamentações, a ginga, são elementos constitutivos da cultura dos povos africanos” (SOUZA, 2001, p. 84), que não eram bem-vistos pela sociedade goiana em questão. Enfatizando a afirmação de que não eram bem-vistos, Souza observa ainda que "para contrapor às festas africanas, a Igreja recomendava, como obrigação, a recitação do terço em família, nas casas, arraiais, fazendas e vilas, todos os dias."

À medida que se esgotava o ouro, no entanto, a povoação decaía e outros meios de subsistência tiveram que ser cultivados pelos goianos, como a pecuária e a agricultura, por exemplo, que propiciaram certa estabilidade econômica a algumas famílias (CHAUL, 1997, 
p. 87). Estas famílias conviviam ainda com os negros africanos e seus descendentes, já que estes continuaram prestando serviços a esses senhores, mesmo depois de libertos. Souza (2001, p. 24) observa que a única posse dos negros libertos, depois da abolição, era a miséria e a fome. Foi nessa sociedade, portanto, integrada por negros pobres e algumas famílias abastadas, que a música continuou sendo realizada. Os escravos continuaram praticando a herança musical dos primeiros tempos, inclusive o batuque, que está na base do Lundu. Rodrigues (1982) e Mendonça (1981), em suas obras, citam principalmente a música sacra e alguma outra de origem profana, como a modinha, por exemplo, mencionam muito a prática dos saraus e serestas pelas famílias mais abastadas ou que com elas conviviam mais de perto, mas, praticamente, não fazem referência à música da parte mais pobre desta sociedade, a música praticada pelos afrodescendentes. A menção ao gênero lundu, lundu dança ou lundu canção, um dos gêneros contemplados por esta pesquisa, só acontece para lembrar que ocorriam na zona boêmia da cidade, a dimensão cultural que não foi privilegiada pela historiografia abordada, o que já evidencia representações relacionadas a essa prática musical e à própria historiografia.

Uma das poucas menções feitas por Mendonça (1981, p. 361) ao lundu, traz a foto do manuscrito de uma polca-lundu de autoria do músico pirenopolino Antônio da Costa Nascimento (o Tonico do Padre), citada como se fosse o próprio lundu, um engano da autora, portanto. O que pôde ser constatado é que se trata de uma parte cavada de um instrumento de banda, provavelmente a requinta, já que não fica claro na foto do manuscrito (Figura 1).

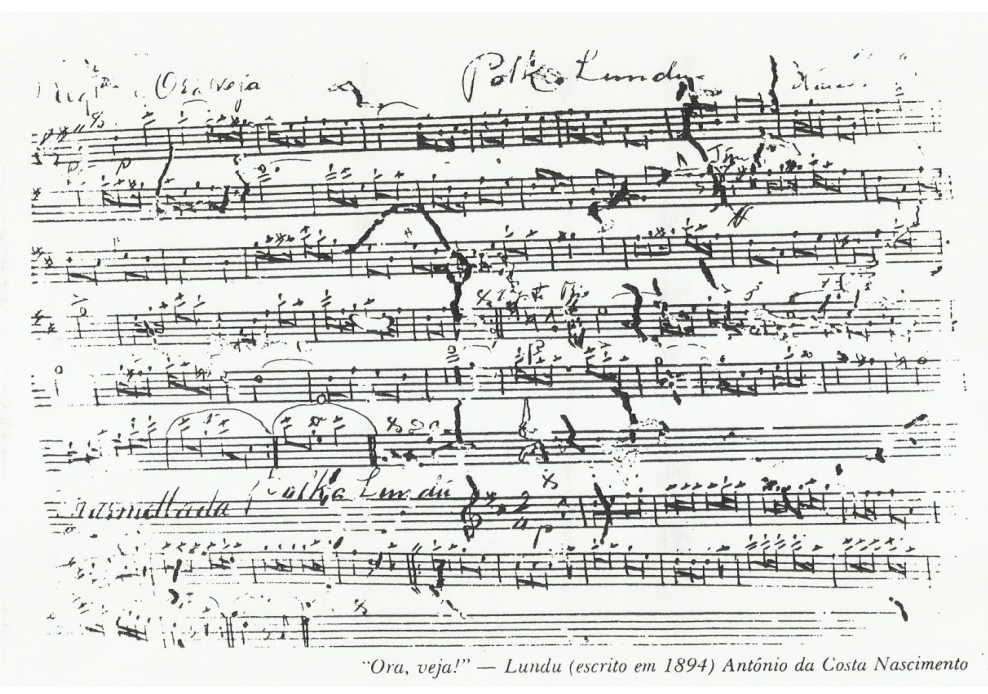

Figura 1 - Manuscrito da Polca-Lundú de Antônio da Costa Nascimento - Tonico do Padre

Fonte: MENDONÇA, Belkiss S. A música em Goiás. Goiânia: Editora UFG, 1981. p. 361.

Este manuscrito provavelmente integra o acervo pessoal da família Pompeo de Pina em Pirenópolis.

As bandas eram cultivadas não só em Pirenópolis, mas também em Vila Boa, desde o século XIX. Pela proximidade e troca que acontecia entre o universo musical das duas localidades oriundas do ciclo do ouro, conforme constatado através da historiografia local, polcas-lundus também foram executadas em Vila Boa pelas bandas, embora essa mesma historiografia não tenha divulgado manuscritos como este.

Na verdade, a polca lundu evidencia a mistura da polca com o lundu, o que já aponta para uma das primeiras manifestações musicais que se desenvolveu rumo a um "modo de tocar" denominado choro, que se tornaria um gênero musical na década de 1910 (CAZES, 1999, p. 21), outro gênero que praticamente não foi mencionado na historiografia consulta- 
da, a não ser para afirmar que não foi praticado em Goiás no recorte de tempo em questão, e, sim, no Rio de Janeiro (RODRIGUES, 1982, p. 113). Delineados alguns elementos do contexto histórico-social abordado, resta discorrer um pouco mais sobre as peculiaridades estilísticas do lundu canção e do choro, que apontaram também para algumas possibilidades relacionadas à sua inserção ou não na sociedade goiana já esboçada.

\section{O lundu, o lundu canção e o choro}

O lundu, conforme Kiefer (1977, p. 31), “descende diretamente do batuque dos negros", de um processo de interação da dança dos africanos e afrodescendentes com o fandango, uma dança que chegou ao Brasil possivelmente através dos europeus. Segundo o autor,

costumava ser dançado o lundu [...] começa a cantoria, que logo cede o passo à atraente dança dos negros. Emprego esse termo como o que mais se coaduna ao divertimento em questão, misto de dança da África e fandango da Espanha e Portugal. (KIEFER, 1977, p. 34)

A história do lundu teve início através da dança e canto, portanto, mas com o passar do tempo ramificou-se também em lundu-canção. Como já observado, foi atribuído a Domingos Caldas Barbosa, um brasileiro que cantava modinhas em Portugal, a introdução do lundu canção na corte portuguesa do final do século XVIII. A pesquisa de Lima (2001) confirma que a confusão inicial entre modinha e lundu neste período era frequente, sendo possível encontrar no manuscrito MSS 1596 (Modinhas do Brazil)² modinhas que são quase lundus e lundus que são quase modinhas. Este manuscrito se encontra hoje na Biblioteca da Ajuda/ Portugal, cuja autoria é atribuída, embora com muita polêmica ${ }^{3}$, segundo o próprio Lima (2001, p. 15), a Domingos Caldas Barbosa. O contato com essa obra, no entanto, possibilitou observar que a modinha n. 5, Os me deixas que tu dás, exemplificada pela Figura 2, se forem consideradas as suas características estilísticas, pode ser considerada um lundu. Uma destas características pode ser percebida através da letra, que revela um teor picante, e uma proximidade muito grande do escravo com a "nhanhazinha".

Os me deixas q’tu das
Quando a gentes pega em ti
São coizinhas tão mimozas
Que nas outras nunca vi
Muito gosto da nhanhazinha
De andar bulindo contigo
Quando vejo que comigo
Tu estas infadadinha

Ficas tão mugangueirinha Que muito me satisfas Esse mando que te vás

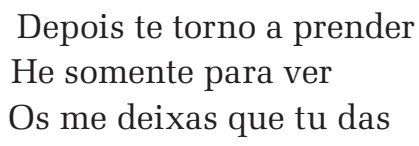

Já a análise de organização sonora, de acordo também com Lima (2010, p. 180), tem revelado um misto de elementos de origem afro-brasileira e elementos da música europeia do período, sobretudo, pré-clássico. No primeiro caso, a presença forte de uma contrametricidade básica, muitas vezes denominada de forma simplificada de síncope, e que já indica um elemento brasileiro resultante da fusão de dois sistemas rítmicos: o europeu e o africano (SANDRONI, 2001, p. 27 e 61). Essa contrametricidade se torna mais característica quando se junta ao texto picante, que evidencia termos utilizados pelos africanos e afrodescendentes que remetem a relações mais próximas entre escravo/senhor, como nhanhá, neguinho, quindim etc. Tinhorão (2013, p. 61), ao se referir ao lundu, discorre também sobre "chulice" 
como sinônimo de "denguice", menciona uma "moleza brasileira" que remete à "moleza brasileira que os europeus denunciavam no caráter da gente da colônia portuguesa da América”. Kiefer (1977, p. 39), comentando Tinhorão, acrescenta a expressão "lascivo-jocosa”. Sandroni (2001, p. 53) já observa que com o desenvolvimento do lundu canção no cenário carioca do século XIX, a palavra mulata passou também a ser muito utilizada, e a crítica social e o humor se tornaram constantes.

As relações com a música europeia, por sua vez, aparecem, sobretudo, através da ornamentação melódica, do compasso geralmente binário, da quadratura das frases, da centralidade no emprego do sistema tonal e, muitas vezes, da utilização de acompanhamento arpejado (LIMA, 2010, p. 180). A Figura 2 revela algumas dessas peculiaridades estilísticas.

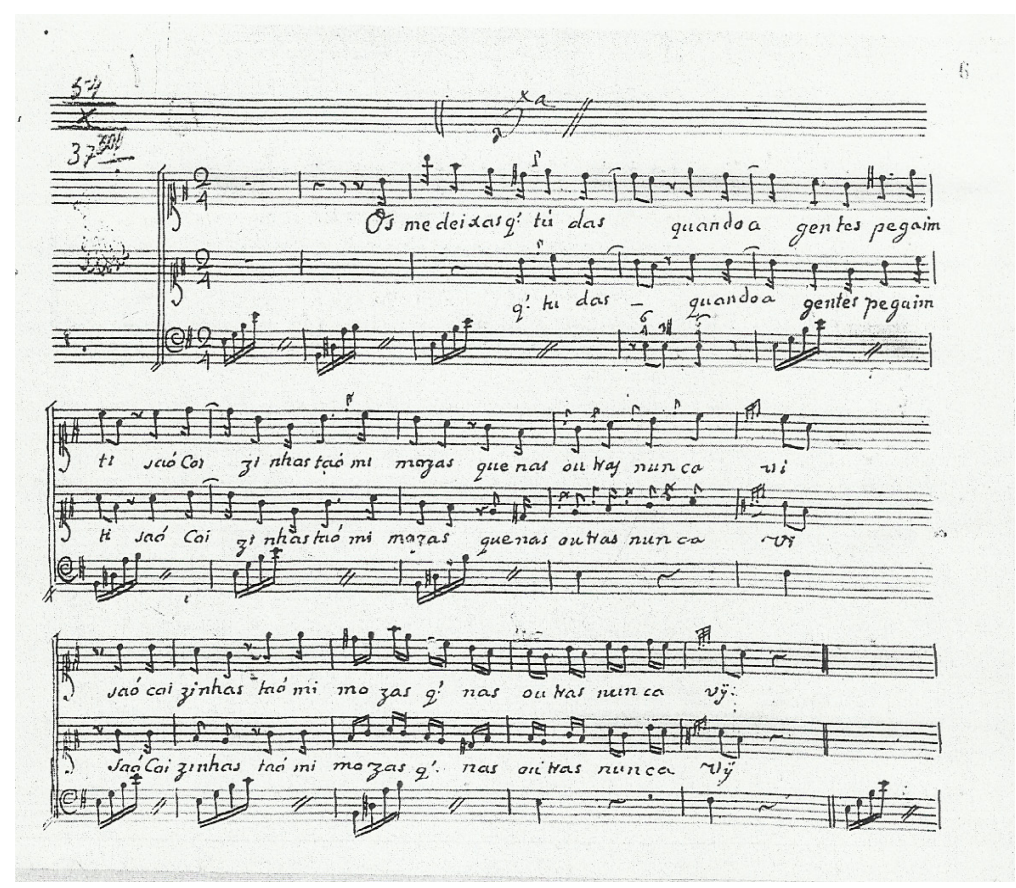

Figura 2 - Parte inicial do manuscrito da Modinha n. 5 - Os me deixas que tu dás - do MSS 1596, com características estilísticas do lundu

Fonte: LIMA, Edilson. As modinhas do Brasil. São Paulo: EDUSP, 2001. p. 221.

Atualmente esse manuscrito se encontra na Biblioteca da Ajuda em Portugal.

Por outro lado, na segunda metade do século XIX, já incorporando um misto de elementos de origem afro-brasileira e elementos da música europeia, o lundu começou a se hibridar com outros gêneros vindos da Europa, sobretudo a polca. Segundo Kiefer (1977, p. 45), "surgiu desta fusão a polca-lundu, híbrido sem condições de iniciar um novo capítulo na história da música popular brasileira.” Como sem condições de iniciar um novo capítulo na música popular brasileira? Estava aí, segundo autores como Tinhorão (2013, p. 119), se esboçando o embrião do "modo de tocar" as danças de salão europeias que chegaram ao Brasil através das companhias de teatro em meados do século XIX, denominado "choro", que nas primeiras décadas do século XX se transformaria em um gênero. O lundu, a polca e a polca-lundu, portanto, estão diretamente ligados ao desenvolvimento deste gênero instrumental, que também foi contemplado por esta pesquisa.

Os grupos que executavam o choro, sobretudo a partir da atuação do flautista Antônio Calado, eram conhecidos também como grupos de "pau e corda", devido à junção da flauta de ébano com os instrumentos de corda, violões e cavaquinho (DINIZ, 2008, p. 14). À 
flauta se devia a parte do solo, o cavaquinho dava suporte ao violão que ficava responsável pelo contracanto e pelos esquemas modulatórios. O trabalho realizado nos tons mais graves do violão recebia “o nome genérico de baixaria” (TINHORÃO, 2013, p. 119). Os músicos foram denominados chorões e "pertenciam à classe média baixa da sociedade carioca. Eram [...] funcionários de repartições públicas, exerciam trabalhos que permitiam uma Boemia regular" (DINIZ, 2008, p. 14). Tinhorão (2013, p. 121) aborda outro aspecto, afirmando que eram tais grupos que forneciam "música de dança nas casas dos bairros e subúrbios cariocas mais humildes", não pedindo nada em troca que não fosse comida e bebida. Assim sendo, utilizavam estratégias para não permanecer em casas que não disponibilizassem aos músicos o que comer e beber, uma circunstância que permitia que "varassem" a noite na festa, com direito a café da manhã. Daí Diniz afirmar que "ser chorão era ser boêmio" (2008, p. 14). No dizer deste autor,

os chorões não tocavam por dinheiro. Quando eram convidados para um baile sempre arrumavam um jeito de dar um pulinho na cozinha do anfitrião para averiguar se a mesa estava farta de comida e bebida. Caso o "gato estivesse dormindo no fogão" frase que expressava a escassez etílica e gastronômica do lar, inventavam uma desculpa e partiam para outras bandas. Ser chorão era ser boêmio. Os bailes e serenatas acabavam sempre com pãozinho e café pela manhã. (grifo nosso)

Um ambiente que já trazia algo de boemia, portanto, uma boemia que foi se caracterizando como tal principalmente quando os chorões começaram a "esticar" suas performances a outros locais de diversão da cidade (TINHORÃO, 2013, p. 121), sobretudo aqueles que começaram a aparecer com a expansão urbana. Clímaco (2008, p. 104), citando Edinha Diniz, observa:

Com a expansão urbana, no entanto, segundo Edinha Diniz, uma boêmia musical relacionada aos chorões começou gradativamente a acontecer em vários outros locais da cidade, passou a estar ligada às ceias animadas de fins de espetáculos, às reuniões alegres das confeitarias e cafés, ao meio teatral, além dos saraus em casas mais abastadas e dos pagodes em casas modestas. Nesse cenário boêmio/musical, especialmente na década de 1880, o estilo da música dos chorões começou a interagir de forma direta e indireta com os cafés berrantes, assim como no início do século XX interagiu com o teatro de revista. (grifo nosso)

Assim, depois de consumado esse "modo de tocar" a música europeia interagindo com o lundu, numa circunstância que beirava à boemia, surgiu na década de 1910, sobretudo através de Alfredo da Rocha Viana Filho, o Pixinguinha (DINIZ, 2008, p. 26), um gênero musical próximo à forma rondó, já que possuía três partes e muita repetição, sobretudo da parte A. Cumpria bem a funcionalidade do tonal, cada parte sendo modulada para um dos tons importantes do centro tonal em que se encontrava a música. Cultivando um estilo improvisatório fluídico, bem próximo da variação melódica, geralmente se consistia no cerne das rodas de choro que continuavam acontecendo sempre regadas a comida e bebida, na ambiência de afeto, descontração e confraternização, característica do "modo de tocar" as danças europeias de salão. A Figura 3 traz o choro Naquele Tempo, um choro de Pixinguinha e Benedito Lacerda. Composto por volta de 1934, no compasso binário e no tom de Ré menor trabalhado nos seus tons vizinhos, Naquele Tempo é constituído por três partes com repetição constante da parte A; exemplifica bem as primeiras características do gênero mencionadas. 


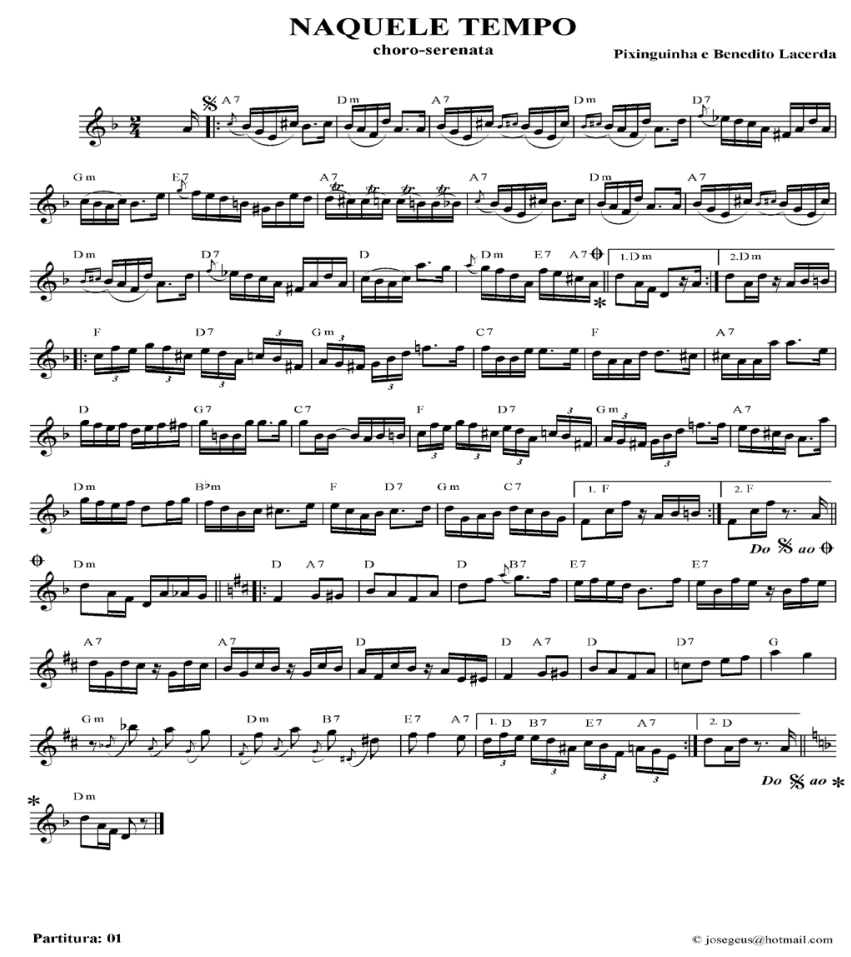

Figura 3 - Choro Naquele Tempo, de Pixinguinha e Benedito Lacerda, mostrando a repetição constante das partes Fonte: IRMÃOS VITALE. Pixinguinha: O melhor do choro brasileiro. São Paulo/ Rio de Janeiro: Irmãos Vitale Editores, 1997. v. 2. p. 24. (cópia da edição de 1947). Editado por José De Geus.

Ao que tudo indica, diante de algumas análises do representacional e de relatos de descendentes de antigos seresteiros goianos, esse gênero foi cultivado de forma tímida em Goiás nas primeiras décadas do século XX, embora a historiografia não tenha mencionado nada sobre essa circunstância. Do mesmo modo, essa historiografia citou rapidamente o lundu-canção, deixando margens para algumas considerações sobre a sua ausência na sociedade que cultivou saraus e serestas.

\section{O lundu e o choro em Goiás}

Em Goiás a busca pelo lundu levou, inicialmente, a encontrar no anexo da obra Viagens pelo Brasil, de Carl Friedrich Philipp von Martius (1794-1868) e Johann Baptist von Spix (1781-1826), intitulado Canções populares brasileiras e melodias indígenas, a referência a uma canção bem próxima da modinha, mas com alguns elementos que remetem ao lundu. O documento, publicado em Munique entre 1823-1831, faz referência ao estado de Goiás juntamente com o estado de Minas Gerais, mostrando que os seus autores transitaram pelos dois estados. Carl Friedrich Philipp von Martius, que transcreveu a canção que será comentada a seguir, por não saber o seu local de origem, descreveu os locais onde foi escutada. Ao que tudo indica, parece que o esboço de gêneros como a modinha e o lundu não foram estranhos totalmente ao estado entre 1817-1820, data em que foi realizada a expedição integrada por Martius e Johann Baptist von Spix. Esta expedição foi enviada pelo "Rei da Baviera para realizar um levantamento botânico, zoológico, mineralógico e etnológico nas províncias de São Paulo, Minas Gerais, Bahia, Pernambuco, Piauí, Maranhão e Amazonas” (CASTAGNA, 2004, p. 9). Segundo Castagna, Martius

também era um bom conhecedor de música e, para enriquecer a publicação, elaborou um anexo musical intitulado Brasilianische Volkslieder und Indianische Melodien 
(Canções populares brasileiras e melodias indígenas), com quatro canções recolhidas em São Paulo, uma em Minas Gerais, uma na Bahia, uma com a indicação “de Minas e Bahia” e outra com a indicação “de Minas e Goiás”, além de um lundu instrumental (sem indicação de localidade) e 14 melodias indígenas.

A cópia apresentada pela Figura 4 evidencia na letra a palavra mulata, um dos termos geralmente encontrados no lundu, ligados a uma menção sensual relacionada à mulher afrodescendente brasileira. A canção esta dividida em duas partes e o compasso é binário composto, que, segundo Rodrigues (1982, p. 113), caracterizou a maior parte das modinhas em Goiás, diferente de outras regiões do país. Na primeira parte, cuja letra lembra elementos do lundu, aparecem os versos: "Huma mulata bonita, não careça rezar / basta o mimo que tem para sua alma salvar" (compassos 1 a 8) e "Mulata se eu podia formar altar, ne'lle te colocaria / para o povo te adorar, te adorar" (compassos 9 a 21). A primeira parte começa com a tonalidade Dó maior, e a segunda parte passa para seu homônimo Dó menor. O canto no manuscrito dos autores (Figura 4) é acompanhado de piano, embora possa ser concordado com Castagna (2004, p. 9) que isto se deve muito mais à necessidade de satisfazer o gosto dos austríacos, já que a obra foi publicada na Áustria. No Brasil, possivelmente, o canto teria sido acompanhado por uma viola. Segundo esse autor,

embora Martius tenha observado, ao passar pela cidade de São Paulo em 1818, que, além da viola, "nenhum outro instrumento é estudado" (SPIX e MARTIUS, v. 1, p. 141), o autor apresentou suas transcrições em versões para canto e piano. [...] Presume-se, portanto, que Martius elaborou um acompanhamento para piano destinado aos seus leitores austríacos e não exatamente por tê-lo observado no Brasil.

Elementos estilísticos da música encontrada em Goiás, portanto, relacionados à trajetória da execução da modinha e do lundu no cenário carioca do início do século XIX, e a certo encontro entre os gêneros, conforme já comentado.

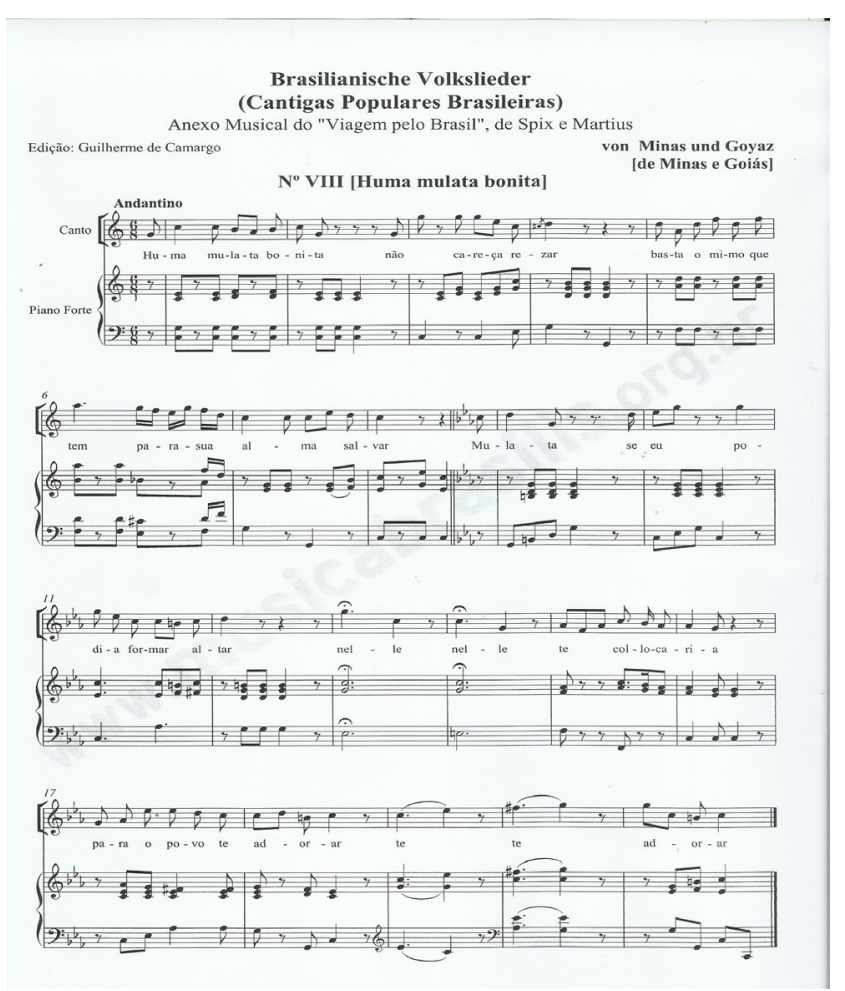

Figura 4 - Canção para voz e piano - Anexo da obra Viagens pelo Brasil, de Martius e Johann Baptist von Spix (1781-1826), indicando a procedência de Minas e Goyas

Editado por Guilherme Camargo

Disponível em: <http://musicabrasilis.org.br/sites/default/files/8_uma_mulata_bonita_svm_0.pdf>. Acesso em: 22 fev. 2018. 
A contínua busca pelo lundu canção em Goiás levou a autores como Mendonça (1981) e Rodrigues (1982), que mencionam rapidamente a sua existência na cidade, embora sempre ligada a uma dimensão cultural diferente da sua, a momentos que exigiam sigilo e discrição por parte daqueles que os integravam. Rodrigues (1982) menciona o lundu quando traz uma citação de Carvalho Ramos relacionada a Antônio Felix de Bulhões Jardim (18451887), membro da família Bulhões, a qual teve uma importante participação na vida cultural da cidade. Lembra que Antônio Felix, além de ter sua profissão como magistrado, era um boêmio que cantava lundus de sua composição.

A toga de magistrado e os labores da imprensa não continham nele o boêmio que ele era. Â noite, nos momentos do sueto, metido num chambre cor de rapé, alegre e galhofeiro, espichava-se na rede, violão em punho e, às galadas de caninha, cantava modinhas e lundus de sua composição para gáudio dos presentes. (CARVALHO RAMOS, ANO apud RODRIGUES, 1982, p. 101)

Mendonça (1981, p. 330) já cita o lundu lembrando palavras da poetisa Cora Coralina que evidenciam a diferença que a sociedade goiana fazia entre esse gênero e a modinha, sendo a modinha aceita e o lundu mal visto. Cunha Mattos, citado por Ribeiro (2001, p. 42) e também mencionado por Mendonça, referindo-se ao lundu dança, afirma que acontecia na zona boêmia da cidade e era dançado apenas por mulheres “ordinárias". Segundo essa autora,

a poetisa Cora Coralina, quando por nós arguida sobre a música em Vila Boa, disse haver, em princípio, profunda restrição das famílias goianas pelo lundu, só sendo ele executado na zona boêmia da cidade. E Cunha Mattos comenta: "as mulheres ordinárias também dansam boas cousas, mas a sua favorita paixão é pelos lundus, em que mostram destreza incomparável”.

A vida goiana "girava em torno da igreja” e de uma vida cultural voltada, sobretudo, para a música erudita e para a literatura, sua sociedade se mostrava preocupada em desenvolver o seu aspecto intelectual, além de se revelar moralista. O jornal Província de Goiáz, em 1870 "public[ou] um anuncio procurando cantoras, mas que deveriam ter boa conduta" (RODRIGUES, 1982, p. 50); e outros periódicos locais da época, como A Tribuna Livre (n. 69, 1879, p. 4; e n. 006, 1880, p. 4), por exemplo, primaram por divulgar normas de boa conduta, sobretudo da mulher. Ao que tudo indica, portanto, teria sido este aspecto cultural e moralista o motivo por não ter sido o lundu canção cultivado pelas "boas famílias" da cidade, por não ter sido preocupação e objeto de estudo dos autores e pesquisadores que assinam a historiografia musical goiana, reconhecidamente descendentes diretos destas "boas famílias”, expressão muito encontrada nessa historiografia. Essa circunstância remete também a práticas reveladoras de representações sociais que evidenciam valorações, categorizações, classificações, de um grupo social.

Realizados estes comentários, importante lembrar que neste cenário goiano do século XIX pós-decadência do ouro, que também assistiu à afirmação econômica e social de algumas famílias que se deram bem, sobretudo com a agropecuária, outra forma de ascensão social era a carreira militar e a religiosa, tendo sido o emprego público também prestigiado. Neste contexto foi surgindo uma classe constituída "pelos professores, farmacêuticos, jornalistas, comerciantes, magistrados e demais funcionários públicos e militares" (RODRIGUES, 1982, p. 34). Esta classe observava "a importância da mulher na sociedade, o interesse pela escola superior e os fatores que levaram a uma particular economia doméstica”. Foi a partir daí, que Rodrigues (1982, p. 15) afirmou ter surgido "o espirito [...] otimista, alegre, extrovertido, dinâmico” do povo goiano. Neste cenário surgiu uma sociedade de mu- 
lheres dinâmicas, empreendedoras, que, dentre outras práticas domésticas e culturais, cultivavam a música através, especialmente, dos saraus lítero-musicais (GUILARDI; CLÍMACO, 2016). Mulheres dinâmicas que apesar destes investimentos e dinamismo, pelos motivos já alegados, renegaram o lundu canção, percebido como a manifestação musical de outra dimensão cultural, ligada de certo modo ao lundu dança que acontecia não somente na zona boêmia, mas também junto aos escravos que permaneceram trabalhando com os seus donos mesmo depois de libertos. Com a crise advinda com a abolição, se a classe dominante estava mal, só havia sobrado mais miséria ainda para aqueles que haviam sido escravos, e "muitos não quiseram abandonar seus senhores e permaneceram trabalhando na casa, recebendo ordenado ou em troca de casa e comida” (RODRIGUES, 1982, p. 42). Continuaram na sua sujeição aos antigos donos, portanto, sem deixar de lembrar suas práticas culturais.

Do mesmo modo que aconteceu com o lundu canção, praticamente não foi localizado vestígio do "modo de tocar" e/ou gênero musical choro. A citação encontrada na escassa historiografia menciona que não foi executado nesta cidade. Esta citação é assinada por Rodrigues (1982, p. 113), quando se refere aos instrumentos que os goianos utilizavam para acompanhar modinhas em suas serestas, fazendo a observação de que em Goiás era muito tocado o bandolim e muito entoada a modinha, diferente do Rio de Janeiro, onde era utilizado o cavaquinho e se executava o choro. Afirma, inclusive, que este gênero musical não se dirigiu ao "centro". Para essa autora,

o violão, [...] foi o instrumento ideal para acompanhar a modinha. Em Goiás o violão plangente harmonizou-se plenamente com o espirito vilaboense, aliando-se ao sonoro bandolim que vai tecendo filigranas melódicas em torno do canto. Interessante notar que no nosso sertão houve a predominância do bandolim e o cavaquinho dominou no litoral com o chorinho que na época não se dirigiu ao centro. A popularidade da flauta, tanto ao gosto português como indígena, veio coroar magnificamente, compondo o trio instrumental modinheiro vilaboense. (grifo nosso)

Apesar de tal citação e de ainda não terem sido encontrados documentos, pode-se pressupor que o gênero tenha sido cultivado nas primeiras décadas do século XX em Goiás. Isto porque desde o final do século XIX muitos filhos das famílias tradicionais goianas iam terminar seus estudos no Rio de Janeiro e lá tinham contato com a boemia estudantil. Este contato, possivelmente, os levou a encontrar o choro na fase em que já circulava por vários locais do Rio de Janeiro, resultantes do desenvolvimento urbano já descrito. A citação de Rodrigues (1982, p. 111) deixa margem para estas considerações, quando reconhece a circunstância ligada à boemia estudantil e afirma que as modinhas "mais recentes", tão caras aos goianos,

vieram [...] através dos estudantes goianos que conviveram com os poetas da época, trazendo consigo, ao regressarem à terra natal, as modinhas mais recentes. [...] Assim como eles, muitos tiveram contato com a boemia estudantil. O caminho era o mesmo do bandeirante, a antiga estrada real, que dos séculos XVIII e XIX passava por Goiás, Jaraguá, Meia-Ponte e Santa-Cruz, rumo à capital paulista.

Se houve a possibilidade do contato com as modinhas mais recentes, deve ter sido possível também o contato com o choro, que marcou tanto a sua presença na antiga capital do país, sobretudo com o desenvolvimento urbano carioca. Por outro lado, pode-se considerar ainda, através da relação dos dados colhidos até agora e da análise do representacional, que o choro tenha sido executado em outros momentos pelos músicos que se dedicavam às serestas, já que os instrumentos eram praticamente os mesmos. E depois, o bandolim, tão requisitado também pelos músicos goianos, conforme análise dos programas de saraus dis- 
poníveis (GUILARDI; CLÍMACO, 2016), era um dos instrumentos relacionados à prática do gênero. Conversando informalmente com um bandolinista filho de um antigo seresteiro da cidade de Goiás, mencionado na pesquisa sobre os saraus e serestas, ele afirmou que seu pai tocava chorinho nesta cidade na primeira metade do século XX. Lembra que chegou a atuar com ele, citando choros e alguns compositores que eram cultivados: "Sim, além das modinhas tinha também o choro [...] tinha aquelas musicas tipo Odeon, tinha outra do Calado, Flor Amorosa, outros chorinhos [...], eram esses que eram chamados chorinhos”. Outro dado que colabora com tal pressuposição são os tangos, polcas, maxixes, compostos por músicos goianos no início do século XX não apenas para bandas, mas também para o carnaval e outros momentos, como foi o caso daqueles compostos por Pedro Valentim Marques (18811939) e Edilberto Santana (1897-1979). Foi o próprio Edilberto Santana, citado por Francis Marques Otto Santana (2008, p. 6), quem observou sobre a produção musical de Pedro Valentim Marques:

Destaco 96 quadrilhas, 116 valsas e 59 tangos, além das músicas nos diversos estilos musicais utilizados em sua época como polca, maxixe, foxtrote, todos constando também das bandas de Joaquim Marques, sendo que neste caso não possuo as partituras, apenas trechos documentais que comprovam tal afirmação. Encontrei nos referidos cadernos, algumas partituras específicas para o Carnaval. Destaco uma Polca de 1913, denominada "Está chaleirando..." (expressão usada no sentindo de alguém que está adulando a outro ou puxando o saco) e três denominadas pelo autor como “marchas carnavalescas" com os títulos: "Alerta goianada!..." (1903), "Carnaval 1908" [...] e "Goianinha" (1909).

Apesar de achar que o músico está fazendo certa confusão com os gêneros, ao falar em polca denominada marcha carnavalesca pelo compositor, consideramos que a referência à polca remete à "polca brasileira" que, segundo autores como Tinhorão (2013) e Diniz (2008), consiste numa das primeiras manifestações de "um modo de tocar" as danças europeias, e que teria deixado as suas marcas estilísticas no gênero choro, que se estabeleceria como tal na cena musical brasileira na década de 1910, segundo agora Cazes (1999, p. 21). A simples referência à polca, mesmo envolta numa possível confusão por parte de Santana, de algum modo mostra a convivência com o gênero.

Seria improvável, portanto, que modinhas, tangos, polcas, maxixes, gêneros muito cultivados no Rio de Janeiro, tivessem logrado êxito em chegar até às terras goianas e o choro e o lundu canção não. Ao que parece, do mesmo modo com o que aconteceu com o lundu canção, a historiografia musical goiana não esteve interessada em levantar este gênero, o que evidencia novamente representações sociais forjadoras de processos identitários, conforme definidas por Chartier (2002, p. 23) e Hall (2014, p. 112), ou seja, valorações, categorizações, classificações, partilhadas por um grupo social.

\section{Considerações finais}

Neste momento do texto é mais fácil compreender porque o lundu canção e o choro não foram cultivados nos saraus goianos, reuniões lítero-musicais que eram realizadas constantemente em residências ou palácio do governo de Vila Boa/Cidade de Goiás no século XIX e no início do século XX, privilegiando a leitura de novos textos e "apresentações artísticas que compreendiam o teatro, a dança e a música” (BORGES, 1998, p. 29). Não estiveram presentes também nas serestas, que, de acordo com Rodrigues (1982, p. 98), consistiam em um evento noturno que reunia músicos para cantar e/ou tocar nas ruas da cidade durante um passeio ou sob a janela de alguém, geralmente debaixo das janelas de uma dama. $\mathrm{O}$ 
que se pode notar, levando em conta os dados colhidos e a abordagem do representacional, é que tanto o lundu canção quanto o choro não estiveram presentes nestas reuniões porque estas se constituíam na diversão e nos momentos de prazer de famílias tradicionais goianas preocupadas com questões intelectuais e moralistas, que praticavam, no máximo, a boemia relacionada às comportadas serestas. Por outro lado, nos saraus e serestas era comum a utilização de instrumentos como o violino, o piano, o violão, a flauta e o bandolim, e o acréscimo do cavaquinho e da percussão comuns às rodas de choro traria outra conotação, remeteria a outra ambientação. Além do mais, o caráter do chorinho e do lundu era vivo, animado, descontraído; e as serestas e saraus, respectivamente, mais românticos e cerimoniosos.

Ao responder às outras perguntas levantadas no início da pesquisa, no entanto, é razoável dizer que o lundu-canção foi praticado em Vila Boa/ Goiás, uma vez que a historiografia não deixa de mencionar a sua existência, mesmo que muito rapidamente. $\mathrm{Na}$ falta de documentos e maiores informações até o momento, não é verossímil precisar exatamente onde, como e por quem foi praticado. Só se pode levantar a possibilidade que tenha sido praticado em momentos mais reservados dos integrantes da elite mencionada, acompanhado pelo violão (viola), conforme a citação de Rodrigues referindo-se ao magistrado da família Bulhões. Acontecia, portanto, em momentos mais descontraídos e discretos da boemia dessa mesma elite que frequentava os saraus, onde, ao que tudo indica, não foi praticado.

Referente ao choro, até agora não foi encontrado nenhum documento, já que a única informação obtida na historiografia musical consultada é que não teria acontecido em Goiás, que seu lugar era o Rio de Janeiro. No entanto, representações se evidenciaram, revelando que pode ter vindo através das influências recebidas no próprio Rio pelos estudantes goianos que para ali se dirigiam com o intuito de terminar seus estudos. Como já visto, há também a possibilidade de ter acontecido em momentos de reuniões de amigos mais descontraídas ou em reuniões mais fechadas dos músicos que praticavam as serestas, muitas vezes contaminados pelo contato com o gênero no Rio de Janeiro, e que já tocavam alguns instrumentos também característicos do choro como flauta, violão e bandolim. Outro sinal é o grande investimento no instrumento bandolim pelos músicos goianos, o que apareceu, inclusive, através da análise dos programas de saraus (GUILARDI; CLÍMACO, 2016). Assim, se até o momento não foi possível chegar a outras fontes que comprovassem o cultivo do choro e das rodas de choro em terras goianas no recorte de tempo em questão, a não ser através do relato do filho de um antigo seresteiro goiano identificado pela pesquisa que levou aos saraus e serestas, foi possível chegar a representações que evidenciaram possibilidades desse cultivo.

Por outro lado, representações também se evidenciaram, quando se leva em consideração que os gêneros lundu canção e choro não foram contemplados pela historiografia musical local, redigida principalmente por mulheres e mulheres descendentes da parte mais abastada da sociedade goiana. Uma elite que "assumia um comportamento moral orientado pela Igreja Católica Apostólica Romana” (SOUZA, 2001 p. 54) e uma vida intelectual relacionada, sobretudo, ao cultivo da música e da literatura. Esta parte da sociedade promovia saraus, investia na música de concerto, na aquisição de cultura, de um modo tal, que apesar da modinha ser muito cultivada nesses eventos lítero-musicais, por seu caráter popular, nunca foi mencionada nos programas encontrados. Deixaram de narrar sobre o que estava ligado à cultura musical de outra dimensão cultural da sociedade e às reuniões ligadas à boemia e à descontração masculina. Deve ser levado em conta, portanto, junto aos dados colhidos até o momento, representações ligadas a essas circunstâncias forjadoras de processos identitários, capazes também de revelar outras facetas da sociedade instituída pela antiga capital goiana. 


\section{Notas}

1 O Arraial de Sant'Anna surgiu no interior do país no período do ciclo do ouro, nas primeiras décadas do século XVIII (1726-1740), segundo Palacín (1995, p. 34). Em 1739 passou a Vila - Vila Boa de Goiás - e em 1818 a Cidade - a Cidade de Goiás (PALACÍN, 1995, p. 36). Foi a capital do estado de Goiás por mais de um século, quando aconteceu a instalação da nova capital, a cidade de Goiânia, na década de 1930.

2 Gérard Behágue foi um dos divulgadores no Brasil da existência dos manuscritos MSS 1595/1596, coletâneas de canções do séc. XVIII, que se encontram na Biblioteca da Ajuda/Portugal: BEHÁGUE, Gérard. MSS 1595/1596: Two eighteenth century anonymous of modinha. Anuário, Tulane University, Lisboa, Biblioteca da Ajuda, v. IV, 1968.

3 Nessa intenção me coloco junto a Lima (2001, p. 15) quando, ao comentar sobre essas circunstâncias polêmicas no seu trabalho com o manuscrito 1596, observa: "A bibliografia existente não nos permite dizer com certeza que as 30 modinhas do manuscrito 1596 são de autoria de Domingos Caldas Barbosa. Duas, no entanto, têm letra desse autor, embora o anonimato do manuscrito nos impeça de confirmar tal afirmação. Ademais, este trabalho propõe-se a analisar prioritariamente o estilo musical das modinhas nele contidas, e não a autoria das mesmas."

\section{Referências}

BORGES, Maria Helena Jaime. A Música e o Piano na Sociedade Goiana (1805/1972). Goiânia: FUNAPE, 1998.

CAMARGO, Guilherme. Viagem de Spix e Von Martius pelo Brasil (1817-1821). Disponível em: $<$ http://musicabrasilis.org.br/sites/default/files/8_uma_mulata_bonita_svm_0.pdf $>$. Acesso em: 22 fev. 2018.

CASTAGNA, Paulo. A modinha e o lundu nos séculos XVIII e XIX. São Paulo: Apostila do curso História da Música Brasileira Instituto de Artes da UNESP, 2004.

CAZES, Henrique. Choro: do quintal ao Municipal. São Paulo: Editora 34, 1999.

CHARTIER, Roger. A História Cultural entre práticas e representações. Rio de Janeiro: DIFEL, 2002.

CHAUL, Nasr Fayad. Caminhos de Goiás. Da construção da decadência aos limites da modernidade. Goiânia: Ed. UFG, 1997.

CLÍMACO, Magda de Miranda. Alegres Dias Chorões: o choro como expressão musical no cotidiano de Brasília. Anos 1960 - tempo presente. 2008. 393 f. Tese (Doutorado) - Instituto de Ciências Humanas - PPGH, Universidade de Brasília, Brasília, 2008.

. Do lundu canção dos salões portugueses ao lundu canção dos cenários carioca e goiano do séc. XIX. In: CONGRESSO INTERNACIONAL - I, 2013, Lisboa. A música no espaço luso-brasileiro: um panorama histórico. Lisboa: Alberto Pacheco Editor, 2013. p. 558-573.

DINIZ, André. Almanaque do choro. Rio de Janeiro: Jorge Zahar. Ed., 2008.

DINIZ, Edinha. Chiquinha Gonzaga. Rio de Janeiro: Rosa dos Tempos, 1999.

GUILARDI, Ludymilla; CLÍMACO, Magda de Miranda. Saraus e Serestas em Goiás: processos identitários e interações com a modinha. In: SIMPÓSIO INTERNACIONAL ÍBERO-AMERICANO, IV./ CONGRESSO NACIONAL DE MUSICOLOGIA DA ABMUS, I., 2016, Belo Horizonte. Anais... Belo Horizonte: Escola de Música UFMG, 2016.

. Quem precisa de identidade? In: SILVA, Tomás Tadeu (Org.). Identidade e Diferença. Petrópolis, RJ: Vozes, 2014. p. 103-133.

IRMÃOS VITALE. Pixinguinha. O melhor do choro brasileiro. São Paulo/ Rio de Janeiro: Irmãos Vitale Editores, 1997. v. 2. p. 24. (cópia da edição de 1947). Editado por J. De Geus.

KIEFER, Bruno. A modinha e o lundu, duas raízes da música popular brasileira. Porto Alegre: Universidade Federal do Rio Grande do Sul, 1977.

LIMA, Edilson de. As modinhas do Brasil. São Paulo: Editora da Universidade de São Paulo, 2001. 
. A Modinha e o Lundu: dois clássicos dos trópicos. 2010. 248 f. Tese (Doutorado em Musicologia) - Escola de Comunicações e Artes, Universidade de São Paulo, São Paulo, 2010.

MENDONÇA, Belkiss S. Carneiro de. A música em Goiás. Goiânia: Editora UFG, 1981.

PALACÍN, Luis; GARCIA, Leônidas Franco; AMADO, Janaína. História de Goiás em Documentos. Goiânia: Editora UFG, 1995.

PINTO, Alexandre G. O Chôro: Reminiscências dos chorões antigos. Rio de Janeiro: Tipografia Glória, 1936.

RIBEIRO, Paulo Rodrigues. Sombras no silêncio da noite: imagens da mulher goiana no século XIX. In: CHAUL, Nasr Fayad; RIBEIRO, Paulo R. Goiás Identidade, paisagem e tradição. Goiânia: Ed. da UCG, 2001. p. 25-56.

RODRIGUES, Maria A. C. de S. A modinha em Vila Boa de Goiás. Goiânia: Editora UFG, 1982.

SANDRONI, Carlos. Feitiço Decente. Rio de janeiro: Zahar, 2001.

SANTANA, Francis Marques Otto. Abram alas para estes carnavais: reconstruindo os carnavais de Vila Boa à nova capital Goiânia. 2008. Disponível em:

$<$ http://www.abant.org.br/conteudo/ANAIS/CD_virtual_26_RBA_de_/trdabalhos>. Acesso em: 28 jul. 2017.

SOUZA, Antônio Rocha de. As irmandades católicas dos negros na cidade de Goiás no século XX. 2001. 123 f. Tese (Mestrado em Ciências da Religião) - Departamento de Ciências Humanas, Universidade Católica de Goiás, Goiânia, 2001.

SPIX, Johann Baptist von; MARTIUS, Carl Friedrich Philipp von. Viagem pelo Brasil 1817-1821. Belo Horizonte: Itatiaia; São Paulo: EDUSP, 1981. 3v. Anexo.

TINHORÃO, José R. História social da música popular brasileira. São Paulo: Ed. 34, 1998.

. Pequena história da música popular. São Paulo: Ed. 34, 2013.

\begin{abstract}
Magda de Miranda Clímaco é professora, pesquisadora e orientadora de trabalhos na Graduação e na Pós-Graduação da Escola de Música e Artes Cênicas da Universidade Federal de Goiás (EMAC/ UFG). Doutora em História Cultural pela Universidade de Brasília (UnB); Mestre em Música pela Universidade Federal de Goiás (UFG). Como pesquisadora integra a coordenação do Laboratório de Musicologia Braz Wilson Pompeo de Pina, vinculado ao Programa de Pós-Graduação - Mestrado em Música da EMAC/ UFG, ao Grupo de Pesquisa "Arte, Educação, Cultura" vinculado ao CNPq e ao Caravelas - Centro de Pesquisas em História da Música Luso Brasileira/ CESEM/ Universidade Nova de Lisboa. Atua nas seguintes linhas de pesquisa: "Música, Cultura e Sociedade”; "Músicas Brasileiras e Processos Identitários”. Desde 2011 integra a Coordenação Geral do Simpósio Internacional de Musicologia promovido anualmente nas cidades de Pirenópolis/ GO e Goiânia/ GO pela Escola de Música e Artes Cênicas da Universidade Federal de Goiás (EMAC/ UFG).
\end{abstract}

Ludmylla Cristina Guilardi é aluna do curso de Música da Escola de Música e Artes Cênicas (EMAC) da Universidade Federal de Goiás (UFG). Pesquisadora do programa de Iniciação Científica (PIBIC) desta instituição nos períodos 2015/2016 e 2016/2017, desenvolveu pesquisas sobre a música na cidade de Vila Boa/ Goiás no final do século XIX e início do século XX. 